\title{
THE RELATIONSHIP BETWEEN INTERNET BANKING
}

\section{AND BANKING FUNCTIONS}

\author{
BILAL AHMAD SHEIKH
}

Research Scholar, Business Administration, Annamalai University, Chennai, Tamil Nadu, India

\begin{abstract}
The usage of Banking Functions through Internet mechanism is comfortable and time saving process; since the adoption rates of different Banking Functions through Internet Banking mechanism is very low. An attempt has been made in the current study to check the variations on Internet Banking between different Banking Functions.

KEYWORDS: E-Banking, Electronic Financial Products, Electronic Non Financial Products \& Behavioural Intention
\end{abstract}

Received: Feb 27, 2018; Accepted: Mar 19, 2018; Published: Apr 20, 2018; Paper Id.: IJESRAPR201816

\section{INTRODUCTION}

\section{Internet Banking}

Internet banking lets you handle many banking activities via your personal computer. For instance, you may use your computer to view your account balance, request transfers between accounts, and pay bills electronically. Internet banking is a system and method in which a personal computer is connected by a network service provider directly to a host computer system of a bank such that customer service requests can be processed automatically without need for intervention by customer service representatives. The system is capable of distinguishing between those customer service requests which are capable of automated fulfillment and those requests which require handling by a customer service representative. The system is integrated with the host computer system of the bank so that the remote banking customer can access other automated services of the bank.

\section{Electronic Financial Products}

All Financial Products are being supported and used through electronic means due to the development of technology (Gupta, 2008). List of important Electronic Financial Products that can be handled with e- Banking by Banking Customers are as follows.

- $\quad$ Electronic Fund Transfer (NEFT RTGS IMPS) through Internet Banking

- Using Debit Card for online Transaction through internet

- Managing Credit card through Internet Banking

- Investments on Derivatives through Internet Banking

- Paying Insurance Premium through Internet Banking

- Mutual funds, Investments through Internet 
- Loan EMI Payments through internet Banking

- Investments on Futures and Options through Internet Banking

- Internet Banking Account

- Online share trading

\section{Electronic Non Financial Products}

Due to the development of technology (Gupta, 2008) all non Financial Products are being supported and used through electronic means and the same process is known as Internet Banking.

According to (Jammu and Kashmir Bank, HDFC Bank, ICICI Bank, AXIS Bank, etc.) List of important Non Financial Products that can be handled with e- Banking by Banking Customers are as follows.

- Electricity bill payment through electronic Banking

- Payment of Train ticket through electronic Banking

- Mobile Recharge through electronic Banking

- DTH Recharge through electronic Banking

- Payment of Bus ticket through electronic Banking

- Landline Bill payment through electronic Banking

- Payment for buying products through electronic Banking

- Payment of Income taxes and other Taxes through electronic Banking

- $\quad$ Payment for Flight Tickets through electronic Banking

- Charity Donations through electronic Banking

\section{REVIEW OF LITERATURE}

Margaret et al., (2000) reports that intentionally adopt Electronic Financial Products and Electronic Non Financial Products can be predicted by attitudinal and perceived behavioural control factors, but not by subjective norms. The attitudinal factors that are significant include relative advantage; compatibility with the respondent's values, experience, and needs; trial ability; and risk. Although the findings of this study show that perceived complexity has a negative relationship with adoption intentions, this relationship is not significant. One possible reason is that since Electronic Financial Products and Electronic Non Financial Products in Singapore is relatively new, most Internet users have yet to try it. As a result, they are unable to effectively assess the complexity of using such systems and the influence that such complexity may have on their intentions. The results of this study have also shown that there are other factors besides attitudinal ones that can help us to better understand the adoption intentions of Digital Banking. Two additional influencing factors (subjective norms and perceived behavioural control) proposed by (Ajzen, 2002), in the theory of planned behaviour, were included in this study. Although subjective norms were not found to significantly influence adoption intentions, perceived behavioural control dimensions were nonetheless found to have significant influences. In particular, self-efficiency toward using Electronic Financial Products and Electronic Non Financial Products and the facilitating 
conditions of perceived government support for Internet commerce were both found to significantly affect intentions to adopt Electronic Financial Products and Electronic Non Financial Product however Mohammad et al., (2012) have reported that e-banking services are being used with increasing frequency in most countries. Electronic banking enhances the development of the banking system, and it is considered as a strategic weapon for banks. Although it provides various benefits for both banks and customers, low level of customers' adoption of electronic banking services is noted in Jordan. Also, electronic banking services cannot achieve expected benefits if it is not used by customers. A research model was developed through integrating TAM with TBP and incorporating five cultural dimensions and perceived risk to provide a comprehensive investigation the results of the study revealed that perceived usefulness and perceived ease of use has a positive and significant impact on customers' attitude toward electronic banking services. Banks should make electronic banking services more useful and usable. They could achieve this by increasing the customers' awareness of the usefulness of using electronic banking services through advertising and long-term customer services, this study used a cross-sectional design. One possible direction for future studies is to conduct a longitudinal study to see whether the variables and their relationships are consistent with time. Second: this study used Hofstede's national cultural framework.

Lichtenstein et al., (2006) reports key findings from an interpretive study of Australian banking, that an understanding of how and why specific factors affect the consumer decision whether or not to bank on the Internet, in the Australian context. A theoretical framework is provided that conceptualizes and links consumer oriented issues influencing adoption of Digital Banking. This study also provides a set of recommendations for Australian banks. Specifically, the findings suggest that convenience is the main motivator for consumers to bank on the internet, while there is a range of other influential factors that may be modulated by banks. This study also highlights the increasing risk acceptance by consumers in regard to internet-based services and the growing importance of offering deep levels of consumer support for such services. Gender differences are also highlighted. Finally, this study suggests that banks will be better able to manage consumer experiences while moving to Electronic Financial Products and Electronic Non Financial Products if they understand that such experiences involve a process of adjustment and learning over time, and not merely the adoption of a new technology.

Jayashree, (2013) studied that Online banking (Digital Banking) has emerged as one of the most profitable ecommerce applications over the last decade. Although several prior research projects have focused on the factors that impact on the adoption of information technology or the Internet, there is limited empirical work which simultaneously captures the success factors (positive factors) and resistance factors explores and integrates the various advantages of online banking to form a positive factor named perceived benefit. In addition, drawing from perceived risk theory, five specific risk facets - financial, security/privacy, performance, social and time risk - are synthesized with perceived benefit as well as integrated with the technology acceptance model (TAM) and theory of planned behaviour (TPB) model to propose a theoretical model to explain the customers' intention to use Online banking. The results of this study indicated that the intention to use online banking is adversely affected mainly by the security/privacy risk, as well as financial risk and is positively affected mainly by perceived benefit, attitude and perceived usefulness. Thompson et al., (2011) explored a research framework based on the theory of planned behaviour (Ajzen, 1985) and the diffusion of innovations theory was used to identify the attitudinal, social and perceived behavioural control factors that would influence the adoption of Digital Banking. The results revealed that attitudinal and perceived behavioural control factors, rather than social influence, play a significant role in influencing the intention to adopt Digital Banking. In particular, perceptions of relative advantage, compatibility, trial ability, and risk toward using the Internet were found to influence intentions to adopt 
Electronic Financial Products. In addition, confidences in using such services as well as perception of government support for electronic commerce were also found to influence intentions Baten, (2010).

\section{OBJECTIVES}

To Study the variations on Internet Banking Adoption between different Banking Functions.

\section{HYPOTHESIS}

H1:Banking Functions does not vary with Internet Banking Adoption.

\section{Sampling Details}

The primary data for the present Study was collected from the Banking Customers and these customers were identified on a random basis from the state of Jammu \& Kashmir The filled up response was collected successfully from 300 respondents, however from collected 300 responses 278 responses were valid and 22 responses were incomplete and hence eliminated from the current study. Hence the sample size for the present work is treated as 278 comprising the Banking customers. Thus, the sampling procedure adopted for the present study is treated as a stratified random sampling method. The primary data for the present study is collected between the Periods June 2017 to August 2017. The data collected were coded and transferred in to Statistical package for Social Science (SPSS) for the purpose of analysis.

\section{DATA ANALYSIS AND DISCUSSION}

\section{Relationship between Intensity Levels of Internet Banking and ATM Usage}

The kind of association that exists between Intensity levels of ATM usage and Intensity levels of Internet Banking usage among Banking customers was defined in hypothesis- 1 taken up and its results are shown in table 1 as the outcome of chi-square analysis and corresponding cross tabulation.

Table 1 Association of Intensity Levels between Internet

Banking and ATM Usage for the Test of Hypothesis-1

\begin{tabular}{|c|c|c|c|c|c|c|c|c|}
\hline \multirow[b]{2}{*}{$\begin{array}{l}\text { Intensity of } \\
\text { ATM Usage }\end{array}$} & \multicolumn{6}{|c|}{ Intensity Levels of Internet Banking } & \multirow{2}{*}{\multicolumn{2}{|c|}{ Total }} \\
\hline & \multicolumn{2}{|c|}{ Non User } & \multicolumn{2}{|c|}{$\begin{array}{c}\text { Low Intensity } \\
\text { Usage }\end{array}$} & \multicolumn{2}{|c|}{$\begin{array}{c}\text { High Intensity } \\
\text { Usage }\end{array}$} & & \\
\hline \multirow{2}{*}{ Non user } & 17 & $1 \%$ & 3 & $1 \%$ & 18 & $2 \%$ & 38 & $4 \%$ \\
\hline & $1 \%$ & ....... & $1 \%$ & $\ldots \ldots$ & $2 \%$ & $\ldots \ldots$ & $4 \%$ & ...... \\
\hline \multirow{2}{*}{$\begin{array}{l}\text { Low Intensity } \\
\text { usage }\end{array}$} & 155 & $13 \%$ & 17 & $1 \%$ & 61 & $5 \%$ & 233 & $19 \%$ \\
\hline & $13 \%$ & $\ldots \ldots$ & $1 \%$ & $\ldots$ & $5 \%$ & ...... & $19 \%$ & ...... \\
\hline \multirow{2}{*}{$\begin{array}{l}\text { High Intensity } \\
\text { usage }\end{array}$} & 518 & $43 \%$ & 109 & $9 \%$ & 302 & $25 \%$ & 929 & $77 \%$ \\
\hline & $43 \%$ & $\ldots$ & $9 \%$ & $\ldots$ & $25 \%$ & $\ldots \ldots$ & $77 \%$ & $\ldots \ldots$ \\
\hline \multirow{2}{*}{ Total } & 690 & $57 \%$ & 129 & $11 \%$ & 381 & $32 \%$ & 1200 & $100 \%$ \\
\hline & $57 \%$ & $\ldots$ & $11 \%$ & $\ldots \ldots$ & $32 \%$ & $\ldots \ldots$ & $100 \%$ & .. \\
\hline \multicolumn{9}{|c|}{ Chi-Square Tests } \\
\hline \multicolumn{2}{|c|}{ Pearson Chi-Square Value } & \multicolumn{2}{|c|}{$13.939^{*}$} & \multicolumn{3}{|c|}{ Degree of fr } & \multicolumn{2}{|l|}{4} \\
\hline
\end{tabular}

* Significant at 5 Percent level; Number of valid cases $\mathrm{N}=1200$;

Source: Computed from primary data

From the results shown, it can be inferred that the chi-square value of 13.939 with 4 degrees of freedom has been found to be Significant at 5 Percent level. Hence, the hypothesis 1 is rejected and hence, the significant levels of association could be established between Intensity levels of ATM and Intensity levels of Internet Banking usage. From the cross tabulation, it can be inferred that higher intensity levels of ATM usage are associated significantly with non-usage of 
Internet Banking applications among the Banking customers.

\section{Relationship between Intensity Levels of Internet Banking usage and Bank Branch Visit}

The kind of association that exists between Intensity levels of Internet Banking usage and Bank Branch visit among Banking customers was defined in hypothesis-1 taken up and its results are shown in table 2 as the outcome of chisquare analysis and corresponding cross tabulation.

Table 2: Association of Intensity Levels between Internet Banking Usage and Bank Branch Visit for the Test of Hypothesis-1

\begin{tabular}{|c|c|c|c|c|c|c|c|c|}
\hline \multirow{2}{*}{$\begin{array}{c}\text { Intensity Of } \\
\text { Bank Branch } \\
\text { Visit }\end{array}$} & \multicolumn{6}{|c|}{ Intensity Levels of Internet Banking } & \multirow{2}{*}{\multicolumn{2}{|c|}{ Total }} \\
\hline & \multicolumn{2}{|c|}{ Non User } & \multicolumn{2}{|c|}{$\begin{array}{c}\text { Low Intensity } \\
\text { Usage }\end{array}$} & \multicolumn{2}{|c|}{$\begin{array}{l}\text { High Intensity } \\
\text { Usage }\end{array}$} & & \\
\hline \multirow{2}{*}{$\begin{array}{l}\text { Low Intensity } \\
\text { usage }\end{array}$} & 300 & $25 \%$ & 16 & $1 \%$ & 63 & $6 \%$ & 379 & $32 \%$ \\
\hline & $25 \%$ & $\ldots \ldots$ & $1 \%$ & ....... & $6 \%$ & $\ldots \ldots$ & $32 \%$ & $\ldots \ldots$ \\
\hline \multirow{2}{*}{$\begin{array}{l}\text { High Intensity } \\
\text { usage }\end{array}$} & 390 & $32 \%$ & 113 & $10 \%$ & 318 & $26 \%$ & 821 & $68 \%$ \\
\hline & $32 \%$ & …‥ & $10 \%$ & $\ldots \ldots$ & $26 \%$ & $\ldots \ldots$ & $68 \%$ & $\ldots \ldots$ \\
\hline \multirow{2}{*}{ Total } & 690 & $57 \%$ & 129 & $11 \%$ & 381 & $82 \%$ & 1200 & $100 \%$ \\
\hline & $57 \%$ & $\ldots \ldots$ & $11 \%$ & $\ldots \ldots$ & $82 \%$ & $\ldots \ldots$ & $100 \%$ & \\
\hline \multicolumn{9}{|c|}{ Chi-Square Tests } \\
\hline \multicolumn{3}{|c|}{ Pearson Chi-Square Value } & $107.069^{*}$ & \multicolumn{3}{|c|}{ Degree of fr } & \multicolumn{2}{|l|}{2} \\
\hline
\end{tabular}

*Significant at 5 Percent level; Number of valid cases $\mathrm{N}=1200$;

Source: Computed from primary data

From the results shown, it can be inferred that the chi-square value of 107.069 with 2 degrees of freedom has been found to be Significant at 5 Percent level, therefore hypothesis2 is rejected and hence, the significant levels of association could be established between Intensity levels of Internet Banking usage and Bank Branch visit. From the cross tabulation, it can be inferred that the high intensity levels of Bank Branch visit is associated significantly with non usage of Internet Banking applications among the Banking customers.

\section{Relationship between Intensity Levels of Internet Banking and Mutual Fund Investment}

The kind of association that exists between Intensity levels of Mutual Fund Investment and Intensity levels of Internet Banking usage among Banking customers was defined in hypothesis- 1 taken up and its results are shown in table 3 as the outcome of chi-square analysis and corresponding cross tabulation. From the results shown, it can be inferred that the chi-square value of 66.303 with 2 degrees of freedom has been found to be Significant at 5 Percent level, therefore the hypothesis 1 is rejected and hence, the significant levels of association could be established between Intensity levels of Mutual Fund Investment and Intensity levels of Internet Banking usage.

Table 3: Association of Intensity Levels between Internet Banking and Mutual Fund Investment for the Test of Hypothesis-1

\begin{tabular}{|c|c|c|c|c|c|c|c|c|}
\hline \multirow{2}{*}{$\begin{array}{l}\text { Mutual Fund } \\
\text { Investment }\end{array}$} & \multicolumn{6}{|c|}{ Intensity Levels of Internet Banking } & \multirow{2}{*}{\multicolumn{2}{|c|}{ Total }} \\
\hline & \multicolumn{2}{|c|}{ Not Used } & \multicolumn{2}{|c|}{$\begin{array}{c}\text { Low Intensity } \\
\text { Usage }\end{array}$} & \multicolumn{2}{|c|}{$\begin{array}{c}\text { High Intensity } \\
\text { Usage }\end{array}$} & & \\
\hline \multirow{2}{*}{$\begin{array}{l}\text { Low Intensity } \\
\text { usage }\end{array}$} & 269 & $67 \%$ & 92 & $22 \%$ & 20 & $5 \%$ & 381 & $94 \%$ \\
\hline & $67 \%$ & $\ldots \ldots$ & $22 \%$ & $\ldots \ldots$ & $5 \%$ & $\ldots \ldots$ & $94 \%$ & ....... \\
\hline \multirow{2}{*}{$\begin{array}{l}\text { High Intensity } \\
\text { usage }\end{array}$} & 10 & $3 \%$ & 1 & $1 \%$ & 12 & $5 \%$ & 23 & $6 \%$ \\
\hline & $3 \%$ & $\ldots \ldots$ & $1 \%$ & ....... & $5 \%$ & $\ldots \ldots \ldots$ & $6 \%$ & $\ldots \ldots$ \\
\hline \multirow{2}{*}{ Total } & 279 & $70 \%$ & 93 & $23 \%$ & 32 & $7 \%$ & 404 & $100 \%$ \\
\hline & $70 \%$ &. & $23 \%$ & $\ldots \ldots$ & $7 \%$ & & $100 \%$ & \\
\hline
\end{tabular}




\begin{tabular}{|c|c|c|c|}
\hline \multicolumn{4}{|c|}{ Table 3: Contd., } \\
\hline \multicolumn{3}{|c|}{ Chi-Square Tests } \\
\hline Pearson Chi-Square Value & $66.303^{*}$ & Degree of freedom & 2 \\
\hline
\end{tabular}

*Significant at 5 Percent level; Number of valid cases $\mathrm{N}=404$;

Source: Computed from primary data

From the cross tabulation, it can be inferred that the low intensity levels of Mutual Fund Investment is associated significantly with non usage of Internet Banking applications among the Banking customers. However, 94 percent of Mutual fund Investors are identified to be with low intensity levels of Mutual fund investments. Also, the adoption of other financial products such as Insurance services, Loan facilities and Credit card facilities are not found to be significantly associated with intensity levels of Internet Banking usage.

\section{The Relationship between Intensity Levels of Availing Insurance} Services and Utilization of Online Insurance Services

The kind of association that exists between Intensity levels of availing Insurance Services and Intensity levels of utilizing online Insurance services was defined in hypothesis-1 taken up and its results are shown in table 4 as the outcome of chi-square analysis and corresponding cross tabulation.

From the results shown, it can be inferred that the chi-square value of 80.267 with 2 degrees of freedom has been found to be Significant at 5 Percent level, therefore the hypothesis 1 is rejected and hence, the significant levels of association could be established between Intensity level of availing Insurance Services and intensity levels of utilizing online Insurance services. From the cross tabulation, it can be inferred that low intensity level of availing Insurance Services is associated significantly with non utilization of online Insurance services among the Banking customers. However, 96 percent of Insurance policy holders are identified to be with low intensity levels on availing Insurance services.

Table 4: Association of Intensity Levels between Availing Insurance Services and Online Insurance Services for the Test of Hypothesis-1

\begin{tabular}{|c|c|c|c|c|c|c|c|c|}
\hline \multirow[b]{2}{*}{$\begin{array}{c}\text { Availing Insurance } \\
\text { Services }\end{array}$} & \multicolumn{6}{|c|}{ Intensity of Utilizing Online Insurance Services } & \multirow{2}{*}{\multicolumn{2}{|c|}{ Total }} \\
\hline & \multicolumn{2}{|c|}{ Not Used } & \multicolumn{2}{|c|}{$\begin{array}{c}\text { Low Intensity } \\
\text { Utilization }\end{array}$} & \multicolumn{2}{|c|}{$\begin{array}{c}\text { High Intensity } \\
\text { Utilization }\end{array}$} & & \\
\hline \multirow{2}{*}{ Low intensity usage } & 475 & $76 \%$ & 109 & $17 \%$ & 19 & $3 \%$ & 603 & $96 \%$ \\
\hline & $76 \%$ & $\ldots \ldots$ & $17 \%$ & ........ & $3 \%$ & & $96 \%$ & \\
\hline \multirow{2}{*}{ High intensity usage } & 7 & $1 \%$ & 4 & $1 \%$ & 9 & $2 \%$ & 20 & $4 \%$ \\
\hline & $1 \%$ & ........ & $1 \%$ & $2 \ldots \ldots$ & $2 \%$ & ........ & $4 \%$ & \\
\hline \multirow{2}{*}{ Total } & 482 & $77 \%$ & 113 & $18 \%$ & 28 & $5 \%$ & 623 & $100 \%$ \\
\hline & $77 \%$ & $\ldots \ldots$ & $18 \%$ & $\ldots$ & $5 \%$ &.. & $100 \%$ & \\
\hline \multicolumn{9}{|c|}{ Chi-Square Tests } \\
\hline
\end{tabular}

*Significant at 5 Percent level; Number of valid cases $\mathrm{N}=623$;

Source: Computed from primary data

\section{Relationship between Intensity Levels of Availing Loan Facilities and Online Loan Payment Facilities}

The kind of association that exists between Intensity levels of availing Loan Facilities and online Loan payment facilities was defined in hypothesis- 1 taken up and its results are shown in table 5 as the outcome of chi-square analysis and corresponding cross tabulation. 
Table 5: Association of Intensity Levels between Availing Loan Facilities and Online Loan Payment Facilities for the Test of Hypothesis-1

\begin{tabular}{|c|c|c|c|c|c|c|c|c|}
\hline \multirow[b]{2}{*}{ Availing Loan Facilities } & \multicolumn{6}{|c|}{ Online Loan Payments Facilities } & \multirow{2}{*}{\multicolumn{2}{|c|}{ Total }} \\
\hline & \multicolumn{2}{|c|}{ Non Users } & \multicolumn{2}{|c|}{$\begin{array}{c}\text { Low Intensity } \\
\text { Usage }\end{array}$} & \multicolumn{2}{|c|}{$\begin{array}{c}\text { High Intensity } \\
\text { Usage }\end{array}$} & & \\
\hline \multirow{2}{*}{ Low intensity usage } & 418 & $65 \%$ & 139 & $22 \%$ & 20 & $3 \%$ & 577 & $90 \%$ \\
\hline & $65 \%$ & $\ldots \ldots$ & $22 \%$ & $\ldots \ldots$ & $3 \%$ & $\ldots \ldots$ & $90 \%$ & $\ldots \ldots$ \\
\hline \multirow{2}{*}{ High intensity usage } & 45 & $7 \%$ & 7 & $1 \%$ & 15 & $2 \%$ & 67 & $10 \%$ \\
\hline & $7 \%$ & 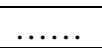 & $1 \%$ & & $2 \%$ & $\ldots \ldots$ & $10 \%$ & \\
\hline \multirow{2}{*}{ Total } & 463 & $72 \%$ & 146 & $23 \%$ & 35 & $5 \%$ & 644 & $100 \%$ \\
\hline & $72 \%$ & $\ldots \ldots$ & $23 \%$ & $\ldots \ldots$ & $5 \%$ & $\ldots$ & $100 \%$ & \\
\hline \multicolumn{9}{|c|}{ Chi-Square Tests } \\
\hline \multicolumn{2}{|l|}{ Pearson Chi-Square Value } & 44.707 & \multicolumn{3}{|c|}{ Degree of freedom } & 2 & & \\
\hline
\end{tabular}

From the results shown, it can be inferred that the chi-square value of 44.707 with 2 degrees of freedom has been found to be Significant at 5 Percent level, therefore the hypothesis 1 is rejected and hence, the significant levels of association could be established between Intensity level of availing Loan Facilities and availing online loan payment facilities. From the cross tabulation, it can be inferred that the low intensity level of availing Loan Facilities is associated significantly with non utilization of online loan payment facilities among the banking customers. However, 90 percent of Banking debtors are identified to be with low intensity levels in availing Loan facilities offered.

\section{Relationship between Intensity Levels of Credit Card Usage and it's Online Management}

The kind of association that exists between Intensity levels of Credit Card Usage and its Online Management was defined in hypothesis-1 taken up and its results are shown in table 6 as the outcome of chi-square analysis and corresponding cross tabulation.

Table 6: Association of Intensity Levels between Usage of Credit Card and its Online Management for the Test of Hypothesis-1

\begin{tabular}{|c|c|c|c|c|c|c|c|c|}
\hline \multirow{2}{*}{$\begin{array}{l}\text { Credit Card } \\
\text { Usage Pattern }\end{array}$} & \multicolumn{6}{|c|}{ Usage of Credit Card through Internet Banking } & \multirow{2}{*}{\multicolumn{2}{|c|}{ Total }} \\
\hline & \multicolumn{2}{|c|}{ Non-Users } & \multicolumn{2}{|c|}{$\begin{array}{c}\text { Low Intensity } \\
\text { Usage } \\
\end{array}$} & \multicolumn{2}{|c|}{$\begin{array}{c}\text { High Intensity } \\
\text { Usage }\end{array}$} & & \\
\hline \multirow{2}{*}{$\begin{array}{l}\text { Low intensity } \\
\text { usage }\end{array}$} & 549 & $77 \%$ & 47 & $7 \%$ & 15 & $2 \%$ & 611 & $86 \%$ \\
\hline & $77 \%$ & ....... & $7 \%$ & ....... & $2 \%$ & $\ldots \ldots$ & $86 \%$ & $\ldots \ldots$ \\
\hline \multirow{2}{*}{$\begin{array}{l}\text { High intensity } \\
\text { usage }\end{array}$} & 74 & $10 \%$ & 4 & $1 \%$ & 20 & $3 \%$ & 98 & $14 \%$ \\
\hline & $10 \%$ & ....... & $1 \%$ & $\ldots \ldots$ & $3 \%$ & $\ldots \ldots$ & $14 \%$ & $\ldots \ldots$ \\
\hline \multirow{2}{*}{ Total } & 623 & $87 \%$ & 51 & $8 \%$ & 35 & $5 \%$ & 709 & $100 \%$ \\
\hline & $87 \%$ & $\ldots \ldots$ & $8 \%$ & $\ldots \ldots$ & $5 \%$ & $\ldots \ldots$ & $100 \%$ & \\
\hline \multicolumn{9}{|c|}{ Chi-Square Tests } \\
\hline \multicolumn{2}{|c|}{ Pearson Chi-Square Value } & \multicolumn{2}{|c|}{$58.650^{*}$} & \multicolumn{3}{|c|}{ Degree of freedom } & 2 & \\
\hline
\end{tabular}

*Significant at 5 Percent level; Number of valid cases $\mathrm{N}=709$;

Source: Computed from primary data

From the results shown, it can be inferred that the chi-square value of 58.650 with 2 degrees of freedom has been found to be Significant at 5 Percent level, therefore the hypothesis 1 is rejected and hence, the significant levels of association could be established between Intensity levels of Credit Card Usage and its Online management. From the cross tabulation, it can be inferred that the low intensity level of Credit Card Usage is associated significantly with non utilization of its Online management features among the Banking customers. However, 86 percent of credit card users are identified to be with low intensity credit card usage pattern. 


\section{Relationship between Intensity Levels of ATM usage for Money Transfer and Intensity of ATM usage}

The kind of association that exists between Intensity levels of ATM usage and Intensity levels of Usage of ATM for Money Transfer was defined in hypothesis- 1 taken up and its results are shown in table 7 as the outcome of chi-square analysis and corresponding cross tabulation.

Table 7: Association of Intensity Levels between Usage of ATM for Money Transfer and ATM usaGe for the Test of Hypothesis-1

\begin{tabular}{|c|c|c|c|c|c|c|c|c|}
\hline \multirow{2}{*}{$\begin{array}{l}\text { Intensity of } \\
\text { ATM Usage }\end{array}$} & \multicolumn{6}{|c|}{ Intensity of Usage of ATM for Money Transfer } & \multirow{2}{*}{\multicolumn{2}{|c|}{ Total }} \\
\hline & \multicolumn{2}{|c|}{ Non-Users } & \multicolumn{2}{|c|}{$\begin{array}{c}\text { Low Intensity } \\
\text { Usage }\end{array}$} & \multicolumn{2}{|c|}{$\begin{array}{l}\text { High Intensity } \\
\text { Usage }\end{array}$} & & \\
\hline \multirow{2}{*}{$\begin{array}{l}\text { Low intensity } \\
\text { usage }\end{array}$} & 91 & $8 \%$ & 101 & $9 \%$ & 41 & $3 \%$ & 233 & $20 \%$ \\
\hline & $8 \%$ & $\ldots \ldots$ & $9 \%$ & $\ldots \ldots$ & $3 \%$ & $\ldots$ & $20 \%$ & ...... \\
\hline \multirow{2}{*}{$\begin{array}{l}\text { High intensity } \\
\text { usage }\end{array}$} & 174 & $15 \%$ & 543 & $47 \%$ & 212 & $18 \%$ & 929 & $80 \%$ \\
\hline & $15 \%$ & ...... & $47 \%$ & & $18 \%$ & ...... & $80 \%$ & $2 \ldots \ldots$ \\
\hline \multirow{2}{*}{ Total } & 265 & $23 \%$ & 644 & $56 \%$ & 253 & $21 \%$ & 1162 & $100 \%$ \\
\hline & $23 \%$ & $\ldots \ldots$ & $56 \%$ & $\ldots \ldots$ & $21 \%$ & $\ldots \ldots$ & $100 \%$ &. \\
\hline \multicolumn{9}{|c|}{ Chi-Square Tests } \\
\hline \multicolumn{3}{|c|}{ Pearson Chi-Square Value } & $.747^{*}$ & \multicolumn{3}{|c|}{ Degree of freedom } & 2 & \\
\hline
\end{tabular}

*Significant at 5 Percent level; Number of valid cases $\mathrm{N}=1162$;

Source: Computed from primary data

From the results shown, it can be inferred that the chi-square value of 43.747 with 2 degrees of freedom has been found to be Significant at 5 Percent level, therefore the hypothesis 1 is rejected and hence, the significant levels of association could be established between Intensity levels of ATM usage and Intensity levels of Usage of ATM for Money Transfer. From the cross tabulation, it can be inferred that the high intensity levels of ATM usage is associated significantly with low intensity levels ATM based money transfer among the Banking customers. In this regard 80 percent of ATM users are identified to be with high intensity ATM usage pattern.

\section{Relationship between Intensity Levels of ATM usage for Money Withdrawal and Intensity of ATM usage}

The kind of association that exists between Intensity levels of ATM usage and Intensity levels of Usage of ATM for Money Withdrawal was defined in hypothesis- 8 taken up and its results are shown in table 8 as the outcome of chisquare analysis and corresponding cross tabulation. From the results shown, it can be inferred that the chi-square value of 4.616 with 2 degrees of freedom has been found to be Significant at 5 Percent level, therefore the hypothesis 1 is rejected and hence, the significant levels of association could be established between Intensity levels of ATM usage and Intensity levels of Usage of ATM for Money withdrawal.

From the cross tabulation, it can be inferred that the high intensity levels of ATM usage is associated significantly with a high intensity usage levels of Money withdrawal through ATM among the Banking customers. Further the usage of ATM for checking account balance could not be significantly associated with intensity levels of ATM usage among Banking customers. 
Table 8: Association of Intensity Levels between Usage of ATM for Money Withdrawal and ATM Usage for the Test of Hypothesis-1

\begin{tabular}{|c|c|c|c|c|c|c|}
\hline \multirow{2}{*}{$\begin{array}{l}\text { Intensity of } \\
\text { ATM Usage }\end{array}$} & \multicolumn{4}{|c|}{$\begin{array}{c}\text { Intensity of Usage of ATM } \\
\text { for Money Withdrawal }\end{array}$} & \multirow{2}{*}{\multicolumn{2}{|c|}{ Total }} \\
\hline & \multicolumn{2}{|c|}{$\begin{array}{c}\text { Low Intensity } \\
\text { Usage }\end{array}$} & \multicolumn{2}{|c|}{$\begin{array}{c}\text { High Intensity } \\
\text { Usage }\end{array}$} & & \\
\hline \multirow{2}{*}{$\begin{array}{l}\text { Low intensity } \\
\text { usage }\end{array}$} & 116 & $10 \%$ & 117 & $10 \%$ & 233 & $20 \%$ \\
\hline & $10 \%$ & $\ldots \ldots$ & $10 \%$ & $\ldots \ldots$ & $20 \%$ & $\ldots \ldots$ \\
\hline \multirow{2}{*}{$\begin{array}{l}\text { High intensity } \\
\text { usage }\end{array}$} & 390 & $34 \%$ & 539 & $46 \%$ & 929 & $80 \%$ \\
\hline & $34 \%$ & $\ldots .$. & $46 \%$ & $\ldots \ldots$ & $80 \%$ & $\ldots \ldots$ \\
\hline \multirow{2}{*}{ Total } & 506 & $44 \%$ & 656 & $56 \%$ & 1162 & $100 \%$ \\
\hline & $44 \%$ & $\ldots \ldots$ & $56 \%$ & 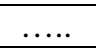 & $100 \%$ & 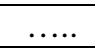 \\
\hline \multicolumn{7}{|c|}{ Chi-Square Tests } \\
\hline \multicolumn{2}{|c|}{ Pearson Chi-Square Value } & 4.616 & \multicolumn{2}{|c|}{ Degree of freedom } & 2 & \\
\hline
\end{tabular}

*Significant at 5 Percent level; Number of valid cases $\mathrm{N}=1200$;

Source: Computed from primary data

\section{FINDINGS}

- The association between Intensity levels of ATM usage and Intensity levels of Internet Banking usage are found to be varying significantly. The high intensity levels of ATM usage are associated significantly with non usage of Internet Banking applications among the Banking customers.

- The association between Intensity levels of Internet Banking usage and Bank Branch visit are found to be varying significantly. The high intensity levels of Bank Branch visit are associated significantly with non usage of Internet Banking applications among the Banking customers.

- The association between Intensity levels of Mutual Fund Investment and Intensity levels of Internet Banking usage is found to be varying significantly. The low intensity levels of Mutual Fund Investment are associated significantly with non usage of Internet Banking applications among the Banking customers.

- The association between Intensity levels of availing Insurance Services and intensity levels of utilizing online Insurance services are found to be varying significantly. The low intensity level of availing Insurance Services is associated significantly with non utilization of online Insurance services among the Banking customers.

- The association between Intensity levels of availing Loan Facilities and availing online loan payment facilities are found to be varying significantly. The low intensity level of availing Loan Facilities is associated significantly with non utilization of online loan payment facilities among the banking customers.

- The association between Intensity levels of Credit Card usage and its online management are found to be varying significantly. The low intensity level of Credit Card usage is associated significantly with non utilization of its Online management features among the Banking customers.

- The associations between Intensity levels of ATM usage and Intensity levels of usage of ATM for Money Transfer are found to be varying significantly. The high intensity levels of ATM usage are associated significantly with low intensity levels of ATM based money transfer among the Banking customers. 
- The associations between Intensity levels of ATM usage and Intensity levels of usage of ATM for Money withdrawal are found to be varying significantly. The high intensity levels of ATM usage are associated significantly with high intensity usage levels of Money withdrawal through ATM among the Banking customers.

\section{CONCLUSIONS}

Internet Banking Adoption is changing physical usage of non Financial Products and Financial Products worldwide. Today, the click of the mouse and mobile banking offers lot of transactions regarding Electronic non Financial Products and Electronic Financial Products. Still the adoption rates of Electronic non Financial Products and Electronic Financial Products are very low. Hence, banking Industry should motivate their customers to adopt Electronic non Financial Products and Electronic Financial Products as maximum banking customers are non-users of Electronic non Financial Products and Financial Products and hence to support the environmental friendly Banking.

\section{REFERENCES}

1. Ajzen, I.(2002). Perceived behavioral control, self-efficacy, locus of control, and the theory of planned behavior. Journal of Applied Social Psychology, 3(2), 665-683.

2. Gupta,P.K,(2008).Internet banking in India: consumer concerns and bank strategies. Global Journal of Business Research, 2(1), 43-51.

3. Hofstede, G. (2007). A European in Asia. Asian Journal of Social Psychology, 10,(3) 16-25.

4. Jayshree, Chavan.(2013).Internet banking-benefits and challenges in an emerging economy. International Journal of Research in Business Management, 1(1), 19-26.

5. Lichtenstein,S. \& Williamson.(2006).understanding consumer adoption of internet banking: an interpretive study in the Australian banking context. Journal of Electronic Commerce Research,7(2),50-66.

6. Rakesh, H. M., \& Ramya, T. J. (2014). A Study on Factors Influencing Consumer Adoption of Internet Banking in India. International Journal of Business and General Management, 3, 49-54.

7. Margaret. \& Thompson. (2000). Factors Influencing the Adoption of Internet Banking. Journal of the Association for Information Systems, 1(1),115-129.

8. Mohamed, Ismail. (2012). Factors Influencing the Adoption of E-banking in Sudan: Perceptions of Retail Banking Clients. Journal of Internet Banking and Commerce, 17(3),01-17.

9. Mohammad, A. Baten,(2010). E-Banking of Economical Prospects in Bangladesh. Journal of Internet Banking and Commerce,15(2),01-10.

10. Sheikh, B. A., \& Rajmohan, P. (2017). Electronic non financial products. EPRA International Journal of Research and development, 2(8), 07-14. 